\title{
Pseudomonas fluorescens affects nutrient dynamics in plant-soil system for melon production
}

\author{
Joaquín Ignacio Martínez ${ }^{1}$, Melisa Gómez-Garrido ${ }^{1}$, María Dolores Gómez-López ${ }^{1}$, Ángel Faz ${ }^{1}$, \\ Silvia Martínez-Martínez ${ }^{1}$, and José Alberto Acosta ${ }^{1^{*}}$
}

'Universidad Politécnica de Cartagena, Gestión, Aprovechamiento y Recuperación de Suelos y Aguas, Paseo Alfonso XIII, 48, 30203 Cartagena, España. "Corresponding author (ja.acosta@upct.es).

Received: 10 September 2018; Accepted: 29 January 2019; doi:10.4067/S0718-58392019000200223

\begin{abstract}
The excessive use of agrochemicals to increase yield and fruit quality can result in soil, freshwater, and groundwater contamination. Designing and using new products based on microorganisms, such as rhizosphere bacteria, could reduce intensive agrochemical application and subsequent potential contamination. Therefore, the effect of a biocontroller (Pseudomonas fluorescens) on the nutrient balance and yield quality of melon (Cucumis melo L.) was evaluated under field conditions. Control and treatment plots without and with a biocontroller applied with an irrigation system were assayed. Soils were monitored by physicochemical and biochemical analysis and plants by nutrient and yield quality analysis during crop development. Pseudomonas fluorescens application significantly promoted salt solubility (416 and $1128 \mu \mathrm{S} \mathrm{cm}^{-1}$ ), available $\mathrm{Cu}$ concentration (3.8 and $\left.4.3 \mathrm{mg} \mathrm{kg}^{-1}\right), \mathrm{P}$ availability (104 and $123 \mathrm{mg} \mathrm{kg}^{-1}$ ), and microbial C biomass (56 and $93 \mathrm{mg} \mathrm{C} \mathrm{kg}^{-1}$ ) for control and treatment plots, respectively. In addition, biocontroller application did not significantly increase soil total $\mathrm{N}$ and exchangeable $\mathrm{Na}, \mathrm{Mg}$, and $\mathrm{K}$ concentrations. Pseudomonas fluorescens also promoted $\mathrm{Mn}, \mathrm{N}, \mathrm{Zn}$, and $\mathrm{P}$ absorption, which causes competition among nutrients, limiting $\mathrm{Cu}, \mathrm{Na}, \mathrm{Ca}$, and $\mathrm{K}$ absorption by melon plants. The $\beta$-glucosidase activity was also responsible for releasing $\mathrm{Fe}, \mathrm{Zn}, \mathrm{Cu}, \mathrm{Mn}, \mathrm{P}$, and $\mathrm{N}$ in the soil. Finally, P. fluorescens application increased fruit size and weight (3.0 to 3.8 and 3.3 to $4.3 \mathrm{~kg}$ for control and biocontroller treatments, respectively); therefore, biofertilization with this bacterium is a sustainable alternative to increase yield and fruit quality without increasing the use of chemical fertilizers and pesticides.
\end{abstract}

Key words: Biocontroller, Cucumis melo, growth promotion, field conditions, biochemical properties.

\section{INTRODUCTION}

Traditional intensive agriculture uses a large amount of agrochemicals (inorganic fertilizers and pesticides) to increase yield and fruit quality; however, the excessive use of these products can result in soil, freshwater, and groundwater contamination, which has generated deep concern for management, farmers, and consumers.

Given the need to continue feeding the current ( 7 billion) and future world population ( 11 billion), new environmentally friendly technologies have recently emerged to increase food production. These will allow the decrease or at least no increase in the use of chemical fertilizers, pesticides, and other artificial supplements (Esitken et al., 2005; Bhattacharyya and Jha, 2012).

One of these new technologies uses effective microorganisms. The role of bacteria from the rhizosphere or rhizobacteria, isolated from different grasses has been studied for decades (Boddey et al., 1995). These associative bacteria are considered as plant growth-promoting rhizobacteria (PGPR) because of their ability to stimulate plant growth through mechanisms such as biological $\mathrm{N}$ fixation, growth-regulating substance production, mineral and nutrient solubilization, increased root volume, and systemic induction of pathogen resistance (Dobbelaere et al., 2003). 
Numerous studies show that the incorporation of these bacteria to seeds or seedlings promotes crop development, notably increases root vigor, and the resistance to pathogen attack (Core, 2005; Fu et al., 2017). This resistance to certain pathogens might be due to the production of antibiotic compounds and enzymes that induce systemic resistance. Crops inoculated with PGPR generate some resistance to drought, salinity, or nutritional deficiency; this is due to the increase of radical development through phytohormones (auxins and cytokines), which have positive effects on plant growth (Yang et al., 2009). However, there is little information about the effect of plant growth-promoting (PGP) bacteria on soil physicochemical and biochemical properties and nutrient balance in soil-plant systems.

We selected melon (Cucumis melo L.) because it is one of the most widespread crops globally, and it contains large amounts of $\mathrm{K}, \mathrm{Mg}, \mathrm{Ca}, \mathrm{P}, \mathrm{Fe}$, and vitamins $\mathrm{A}, \mathrm{B}$, and $\mathrm{C}$. Melon is also one of the richest fruit sources of Na. These properties and its consumption help reduce the risk of heart disease, degenerative diseases, and cancer (Loster, 2008). Therefore, the main objective of this study was to evaluate the effect of Pseudomonas fluorescens (biocontroller) in the evolution of both soil physicochemical and biochemical properties as well as study its effect on melon nutritional balance and yield quality.

\section{MATERIALS AND METHODS}

\section{Crop and experimental conditions}

The experiment was conducted in Murcia province ( $38^{\circ} 04^{\prime} 37^{\prime \prime} \mathrm{N}, 01^{\circ} 25^{\prime} 58^{\prime \prime} ; 313 \mathrm{~m}$ a.s.l.) in southeast Spain. The climate is Mediterranean with mean annual precipitation of $293 \mathrm{~mm}$ and mean annual temperature of $16^{\circ} \mathrm{C}(1998-2014)$. During the crop period (June-September 2014), means for rainfall and temperature were $4 \mathrm{~mm}$ and $25.6{ }^{\circ} \mathrm{C}$, respectively. The soil was classified as Typic haplocalcid (USDA Soil Taxonomy). The study area is part of a melon (Cucumis melo L.) production farm (4.4 ha). Experimental plots were located in the central area of the farm. All plots were irrigated with an irrigation head, which consists of the following components: pumping equipment which is one pump providing water flow with the pressure required by the irrigation system for the plots, filter equipment containing two filtering units, that is, one with two sand filters and the other with two ring filters, and fertilizer injection equipment which handles fertilizer input to the irrigation water. Irrigation water used for all plots had the following composition: $\mathrm{pH} 7.74 \pm 0.2,1.36 \pm 0.3$ $\mathrm{dS} \mathrm{m}^{-1}, 255 \pm 24 \mathrm{mg} \mathrm{L}^{-1}$ chlorides, $<0.07 \mathrm{mg} \mathrm{L}^{-1}$ nitrites, $5.28 \pm 0.84 \mathrm{mg} \mathrm{L}^{-1}$ nitrates, $97.25 \pm 16.54 \mathrm{mg} \mathrm{L}^{-1}$ sulfates, $169 \pm$ $34 \mathrm{mg} \mathrm{Na} \mathrm{L}{ }^{-1}, 10.25 \pm 2.61 \mathrm{mg} \mathrm{K} \mathrm{L}^{-1}, 45.9 \pm 7.6 \mathrm{mg} \mathrm{Ca} \mathrm{L}^{-1}$, and $28.34 \pm 8.64 \mathrm{mg} \mathrm{Mg} \mathrm{L}^{-1}$.

The experimental design consisted of six $50 \mathrm{~m}^{2}$ plots. The biocontroller (P. fluorescens) was applied in three plots with a recommended commercial dose of $1 \mathrm{~kg} \mathrm{ha}^{-1}$ and the other three plots were used as controls (without biocontroller application). The biocontroller consisted of P. fluorescens $10^{9} \mathrm{ufc}^{-1}$ and seaweed extract (Ascophyllum nodosum) as organic substrate, $\mathrm{pH}$ was $8 \pm 0.5$, and no macro- and micronutrients were detected. The main phytohormones identified in the seaweed extracts were auxins, cytokinins, and gibberellins (Tuhy et al., 2013).

The crop was transplanted on 3 June and the biocontroller was applied on 12 June. The biocontroller application was $15 \mathrm{~g}$ product (powder) dissolved in $25 \mathrm{~L}$ irrigation water and injected into the irrigation system. All the plots received conventional irrigation, fertilization, and phytosanitary treatments (treatments and control plots) during crop development. The first, second, and final melon harvest were on 14 August, 21 August, and 4 September, respectively. The final melon harvest coincided with the last soil sampling.

Two soil samplings were taken for physicochemical characterization at the beginning of the crop ( 3 June) and at final harvest (third harvest, 4 September). The number of soil samples was calculated as 6 plots ( 3 treated +3 control $) \times 1$ sample/plot $\times 2$ sampling periods $=12$ soil samples.

For biochemical and nutritional characterization, soil samples were taken at the beginning of the crop (3 June), 1 mo after the biocontroller application ( 12 July), and at the first, second, and third harvests ( 14 and 21 August and 4 September, respectively). Therefore, for biochemical and nutritional analysis, the number of soil samples was 6 plots ( 3 treated +3 control $) \times 1$ sample/plot $\times 5$ samplings periods $=30$ soil samples. Each soil sample consisted of five sub-samples, which were collected from the $0-30 \mathrm{~cm}$ depth.

Four plant samplings for nutrient balance were taken. The first sampling was done 1 mo after the biocontroller application and the other three samplings coincided with the first, second, and third harvests. Three plants were collected in each plot; they were symptom-free of nutritional deficiencies, physiological disorders, and/or diseases. Plant materials 
(leaves and fruit rind separately) were taken for laboratory analysis. The number of plant samples for each analysis was 6 plots $\times 1$ sample/plot $\times 2$ parts (leaves and fruit rind) $/$ plant $\times 4$ samplings $=48$ plant material samples.

Eight plants per plot and per harvest were randomly selected for yield quality analysis; therefore, the number of analyzed samples was 6 plots $\times 8$ melon fruit/plot $\times 3$ samplings $=144$ samples. Yield was calculated based on the number and weight of melons harvested per plot and per treatment.

\section{Analytical methods}

Soil samples were air-dried and sieved $(<2 \mathrm{~mm}$ sieve) before analyses. Soil $\mathrm{pH}$ was measured in deionized water $(1: 1$ w/v) with a pH meter (CRISON-Basic 20, Barcelona, Spain), while electrical conductivity (EC) was measured in a 1:5 soil:water solution with an EC-meter (CRISON-Basic 20, Barcelona, Spain). The percentage of sand, clay, and silt was determined by the Bouyoucos hydrometer method. Total organic $\mathrm{C}$ (TOC) and inorganic $\mathrm{C}$ (carbonates) were determined by the LECO CHNS Elemental Analysis. Soluble anions and cations were determined by ionic chromatography (Metrohm-850 professional IC Anions, Herisau, Switzerland) in deionized water (1:5 w/v) (Zwikel et al., 2007). The cation exchange capacity (CEC) was determined according to Chapman (1965). Available P was measured by the sodiumbicarbonate extraction-based Olsen-P method (Burt, 2004), while the bioavailable minor elements ( $\mathrm{Zn}, \mathrm{Fe}, \mathrm{Cu}$, and $\mathrm{Mn}$ ) were estimated by the diethylenetriaminepentaacetic acid (DTPA) method (Lindsay and Norvell, 1978) and measured by atomic absorption spectrometry (PerkinElmer-AAnalyst800, Waltham, Massachusetts, USA). The microbial biomass C (MBC) was determined by the fumigation-extraction method (Vance et al., 1987). Basal respiration $\left(\mathrm{CO}_{2}-\mathrm{C}\right)$ rates were measured by incubating the soil samples $\left(\right.$ at $25^{\circ} \mathrm{C}$ ) in closed chambers with an alkali solution $(\mathrm{NaOH})$ and titrating the unreacted $\mathrm{NaOH}$ with factorized $\mathrm{HCl}$ to the phenolphthalein endpoint after the precipitation of the $\mathrm{CO}_{2}{ }^{3-}$ formed by adding $\mathrm{BaCl}_{2}$ to the alkali solution. Urease activity was determined as the amount of $\mathrm{NH}_{4}{ }^{+}$released from $0.5 \mathrm{~g}$ soil after incubation at $30^{\circ} \mathrm{C}$ in phosphate buffer (pH 7) for 90 min with urea (6.4\%) (Nannipieri et al., 1980). Phosphatase activity was measured by determining the amount of $p$-nitrophenol (PNP) released from $0.5 \mathrm{~g}$ soil after incubation at $37{ }^{\circ} \mathrm{C}$ for 1 $\mathrm{h}$ with the $p$-nitrophenyl phosphate substrate in modified universal buffer (MUB) and with buffer $\mathrm{pH} 6.5$ (Tabatabai and Bremner, 1969). The activity of $\beta$-glucosidase was assayed according to Tabatabai (1982) following the procedure for phosphatase but using $p$-nitrophenyl- $\beta$-D-glucopyranoside as substrate.

The following parameters were evaluated to determine fruit quality: weight, axial and equatorial diameter, shape, pulp and rind thickness, pulp hardness, and sugar content ( ${ }^{\circ}$ Brix). Plant samples were dried and ground prior to laboratory analyses. Nutrient content in plant tissues was determined by the procedure recommended by Madrid et al. (1996). Approximately $0.7 \mathrm{~g}$ ground sample (leaves and rind separately) were calcined at $480{ }^{\circ} \mathrm{C}$ for $24 \mathrm{~h}$ and digested with $0.6 \mathrm{~N}$ $\mathrm{HNO}_{3}$. Total $\mathrm{Na}$ and $\mathrm{K}$ were measured by flame photometry, while $\mathrm{Ca}, \mathrm{Mg}, \mathrm{Zn}, \mathrm{Fe}, \mathrm{Cu}$, and $\mathrm{Mn}$ were determined by the atomic absorption technique (PerkinElmer-AAnalyst 800, Waltham, Massachusetts, USA). Total plant P in the samples was determined from the $\mathrm{HNO}_{3}$ digest by the ammonium molybdate method (Jeffery et al., 1989). Total plant $\mathrm{N}$ in the samples was determined by the Kjeldahl method (Duchaufour, 1970).

\section{Statistical analysis}

Statistical analyses were performed with Excel (descriptive statistics of soil properties) and SPSS 15.0 software for Windows (Norusis, 1993). Differences between treatments were analyzed by the Kruskal-Wallis and Mann-Whitney U tests at $\mathrm{P}<0.05$. Correlation matrix $(\mathrm{CM})$ and principal component analysis $(\mathrm{PCA})$ were used to identify relationships among physicochemical and biochemical properties. The Pearson correlation coefficient ( $r$ ) was used to measure the relationship between these properties, while PCA was used to study the correlations among the physicochemical and biochemical parameters and its clustering into a few factors. Varimax rotation was applied in the PCA analysis, which minimizes the number of factors with high loading on each component.

\section{RESULTS AND DISCUSSION}

\section{Effect of Pseudomonas fluorescens on soil properties}

Table 1 shows the soil properties before the biocontroller application (initial) and after the third harvest (final). The EC values indicated soils without salinity $\left(876 \mu \mathrm{S} \mathrm{cm}^{-1}\right.$ for control plots and $747 \mu \mathrm{S} \mathrm{cm}^{-1}$ for treated plots); however, 
Table 1. Physicochemical and biochemical soil properties before the biocontroller application (Initial) and at harvest (Final). Mean \pm standard deviation $(n=3)$.

\begin{tabular}{|c|c|c|c|c|}
\hline \multirow[b]{2}{*}{ Soil property ${ }^{*}$} & \multicolumn{2}{|c|}{ Control } & \multicolumn{2}{|c|}{ Biocontroller } \\
\hline & Initial & Final & Initial & Final \\
\hline $\mathrm{pH}$ & $7.9 \pm 0.0$ & $8.2 \pm 0.0$ & $7.9 \pm 0.0$ & $8.0 \pm 0.2$ \\
\hline $\mathrm{EC}, \mu \mathrm{S} \mathrm{cm}^{-1}$ & $876.0 \pm 1060.0 \mathrm{bc}^{* *}$ & $416.0 \pm 152.0 \mathrm{a}$ & $747.0 \pm 117.0 \mathrm{ab}$ & $1128.0 \pm 158.0 \mathrm{c}$ \\
\hline $\mathrm{CaCO}_{3}, \%$ & $45.6 \pm 0.9 \mathrm{a}$ & $49.2 \pm 0.9 b$ & $46.3 \pm 0.9 \mathrm{a}$ & $48.7 \pm 0.3 b$ \\
\hline TOC, $\%$ & $1.1 \pm 0.0$ & $1.1 \pm 0.1$ & $1.1 \pm 0.1$ & $1.1 \pm 0.1$ \\
\hline $\mathrm{CEC}, \mathrm{cmol}_{(+)} \mathrm{kg}^{-1}$ & $13.7 \pm 3.1$ & $13.2 \pm 3.2$ & $13.3 \pm 1.6$ & $13.4 \pm 0.7$ \\
\hline Clay, \% & $32.9 \pm 1.2$ & $33.6 \pm 0.0$ & $32.9 \pm 1.2$ & $32.9 \pm 1.2$ \\
\hline Silt, \% & $35.3 \pm 1.2$ & $37.4 \pm 1.2$ & $32.7 \pm 6.1$ & $30.4 \pm 2.3$ \\
\hline Sand, $\%$ & $31.7 \pm 1.2$ & $29.0 \pm 1.2$ & $34.4 \pm 5.3$ & $36.7 \pm 2.0$ \\
\hline $\mathrm{Cl}^{-}, \mathrm{mg} \mathrm{kg}^{-1}$ & $270.0 \pm 31.0 \mathrm{~b}$ & $43.1 \pm 24 \mathrm{a}$ & $260.0 \pm 54.0 \mathrm{~b}$ & $388.0 \pm 87.0 \mathrm{c}$ \\
\hline $\mathrm{NO}_{2}^{-}, \mathrm{mg} \mathrm{kg}^{-1}$ & $2.7 \pm 0.3 b$ & $1.0 \pm 0.2 \mathrm{a}$ & $3.9 \pm 0.2 \mathrm{c}$ & $0.9 \pm 0.1 \mathrm{a}$ \\
\hline $\mathrm{NO}_{3}^{-}, \mathrm{mg} \mathrm{kg}^{-1}$ & $346.0 \pm 61.0 \mathrm{~b}$ & $16.2 \pm 9.0 \mathrm{a}$ & $359.0 \pm 55.0 \mathrm{bc}$ & $554.0 \pm 211.0 \mathrm{c}$ \\
\hline $\mathrm{PO}_{4}{ }^{3-}, \mathrm{mg} \mathrm{kg}^{-1}$ & $8.3 \pm 0.8$ & $9.4 \pm 5.6$ & $10.8 \pm 2.0$ & $6.6 \pm 0.9$ \\
\hline $\mathrm{SO}_{4}{ }^{2-}, \mathrm{mg} \mathrm{kg}^{-1}$ & $1262.0 \pm 154.0$ & $679.0 \pm 380.0$ & $1031.0 \pm 62.0$ & $1266.0 \pm 369.0$ \\
\hline Available $\mathrm{Fe}, \mathrm{mg} \mathrm{kg}^{-1}$ & $5.4 \pm 0.4 \mathrm{a}$ & $15.0 \pm 0.4 \mathrm{~b}$ & $5.1 \pm 6.0 \mathrm{a}$ & $11.8 \pm 1.7 \mathrm{~b}$ \\
\hline Available $\mathrm{Zn}, \mathrm{mg} \mathrm{kg}^{-1}$ & $10.1 \pm 1.0$ & $11.7 \pm 0.9$ & $10.1 \pm 0.2$ & $12.5 \pm 1.7$ \\
\hline Available $\mathrm{Cu}, \mathrm{mg} \mathrm{kg}^{-1}$ & $3.2 \pm 0.2 \mathrm{a}$ & $3.8 \pm 0.2 b$ & $3.6 \pm 0.2 \mathrm{ab}$ & $4.3 \pm 0.3 c$ \\
\hline Available $\mathrm{Mn}, \mathrm{mg} \mathrm{kg}^{-1}$ & $8.5 \pm 0.8 \mathrm{a}$ & $13.5 \pm 1.4 \mathrm{~b}$ & $8.6 \pm 0.4 a$ & $13.3 \pm 1.2 b$ \\
\hline Olsen $\mathrm{P}, \mathrm{mg} \mathrm{kg}^{-1}$ & $74.0 \pm 6 a$ & $104.0 \pm 11.0 \mathrm{~b}$ & $83 \pm 6.0 \mathrm{a}$ & $123.0 \pm 3.0 \mathrm{c}$ \\
\hline Total $\mathrm{N}, \mathrm{g} \mathrm{kg}^{-1}$ & $0.8 \pm 0.2$ & $1.0 \pm 0.1$ & $0.7 \pm 0.1$ & $1.1 \pm 0.2$ \\
\hline Exchangeable $\mathrm{Ca}, \mathrm{cmol}_{(+)} \mathrm{kg}^{-1}$ & $11.0 \pm 0.0$ & $12.0 \pm 0.5$ & $11.1 \pm 0.5$ & $12.0 \pm 0.9$ \\
\hline Exchangeable $\mathrm{Na}, \mathrm{cmol}_{(+)} \mathrm{kg}^{-1}$ & $0.8 \pm 0.1$ & $0.4 \pm 0.0$ & $0.8 \pm 0.1$ & $0.7 \pm 0.5$ \\
\hline Exchangeable $\mathrm{Mg}, \mathrm{cmol}_{(+)} \mathrm{kg}^{-1}$ & $1.1 \pm 0.0$ & $0.8 \pm 0.3$ & $1.0 \pm 0.4$ & $0.6 \pm 0.3$ \\
\hline Exchangeable $\mathrm{K}, \mathrm{cmol}_{(+)} \mathrm{kg}^{-1}$ & $0.6 \pm 0.1$ & $0.4 \pm 0.2$ & $0.6 \pm 0.1$ & $0.3 \pm 0.1$ \\
\hline $\mathrm{BR}$, mg C-CO $\mathrm{kg}^{-1} \mathrm{~h}^{-1}$ & $2.5 \pm 1.1$ & $2.6 \pm 1.5$ & $2.6 \pm 1.8$ & $2.9 \pm 1.4$ \\
\hline $\mathrm{MBC}, \mathrm{mg} \mathrm{C} \mathrm{kg}{ }^{-1}$ & $85.0 \pm 3.0 \mathrm{~b}$ & $56.0 \pm 5.0 \mathrm{a}$ & $84.0 \pm 5.0 \mathrm{~b}$ & $93.0 \pm 1.0 \mathrm{c}$ \\
\hline$\beta$-Glucosidase, $\mu \mathrm{mol} \mathrm{PNP} \mathrm{g}^{-1} \mathrm{~h}^{-1}$ & $0.2 \pm 0.0$ & $0.2 \pm 0.0$ & $0.2 \pm 1.4$ & $0.2 \pm 0.0$ \\
\hline Phosphatase, $\mu \mathrm{mol} \mathrm{PNP}^{-1} \mathrm{~h}^{-1}$ & $0.7 \pm 0.1$ & $0.7 \pm 0.3$ & $0.8 \pm 0.0$ & $0.6 \pm 0.1$ \\
\hline Urease, $\mu \mathrm{mol} \mathrm{PNP} \mathrm{g}^{-1} \mathrm{~h}^{-1}$ & $0.4 \pm 0.0$ & $0.2 \pm 0.0$ & $0.4 \pm 0.0$ & $0.2 \pm 0.0$ \\
\hline
\end{tabular}

${ }^{*}$ EC: Electrical conductivity; TOC: total organic carbon; CEC: cation exchange capacity; BR: basal respiration; MBC: microbial biomass C; PNP: p-nitrophenol.

**Any two means within a row not followed by the same letter are significantly different at $\mathrm{P}<0.05$.

significant differences were observed in the final sampling between treatments in which the control and biocontroller plot values decreased $\left(416 \mu \mathrm{S} \mathrm{cm}^{-1}\right)$ and increased $\left(1128 \mu \mathrm{S} \mathrm{cm}^{-1}\right)$, respectively. Given that the same volume and quality of irrigation water was applied to all plots, these results suggest that the biocontroller probably promotes salt solubility, especially of chlorides.

The $\mathrm{pH}, \mathrm{TOC}, \mathrm{CEC}$, and texture values, which ranged from 7.9 to $8.0,1.1 \%$, and 13.2 to $13.7 \mathrm{meq} 100 \mathrm{~g}^{-1}$, respectively, were similar during the experiment and were not affected by the biocontroller application. These results are similar to those reported by Mukhtar et al. (2017), who found no differences in $\mathrm{pH}$ and texture after applying phosphate-solubilizing biofertilizer to a wheat crop. In contrast, Singh and Reddy (2012) reported an increase in soil organic C in bio-inoculated soil compared with the control. However, carbonate content was slightly higher in the final sampling for both treatments, ranging from $45.6 \%$ to $49.2 \%$ and $46.3 \%$ to $48.7 \%$ for the control and treatment plots, respectively; this increment was not attributable to the biocontroller application. As for the macronutrient content, available $\mathrm{P}$ was the only macronutrient that exhibited significantly higher concentrations with respect to the start of the experiment $\left(74 \mathrm{mg} \mathrm{kg}^{-1}\right.$ for control plots and $83 \mathrm{mg} \mathrm{kg}^{-1}$ for treated plots) and at final harvest (104 mg kg${ }^{-1}$ for control plots and $123 \mathrm{mg} \mathrm{kg}^{-1}$ for treated plots) between the control and biocontroller treatments (Table 1, Figure 1). The available P concentration was significantly higher at the first harvest, and remained higher than the control treatment until the end of the crop, leaving a source of bioavailable $\mathrm{P}$ for the next crop. According to Chen et al. (2004) and Hayat et al. (2010), rhizobacteria promote phosphate solubilization by increasing the soil available $\mathrm{P}$ concentration. The primary mechanisms of $\mathrm{P}$ solubilization are $\mathrm{H}^{+}$excretion, organic acid production, and acid phosphatase biosynthesis (Behera et al., 2014).

For total $\mathrm{N}$, the increase between initial $\left(0.8\right.$ and $0.7 \mathrm{~g} \mathrm{~kg}^{-1}$ for control and treatment plots, respectively) and final samplings for both treatments (1.0 and $1.1 \mathrm{~g} \mathrm{~kg}^{-1}$ for control and treatment plots, respectively) was nonsignificant 
Figure 1. Evolution of total nitrogen and available phosphorus in the control and biocontroller treatment plots.
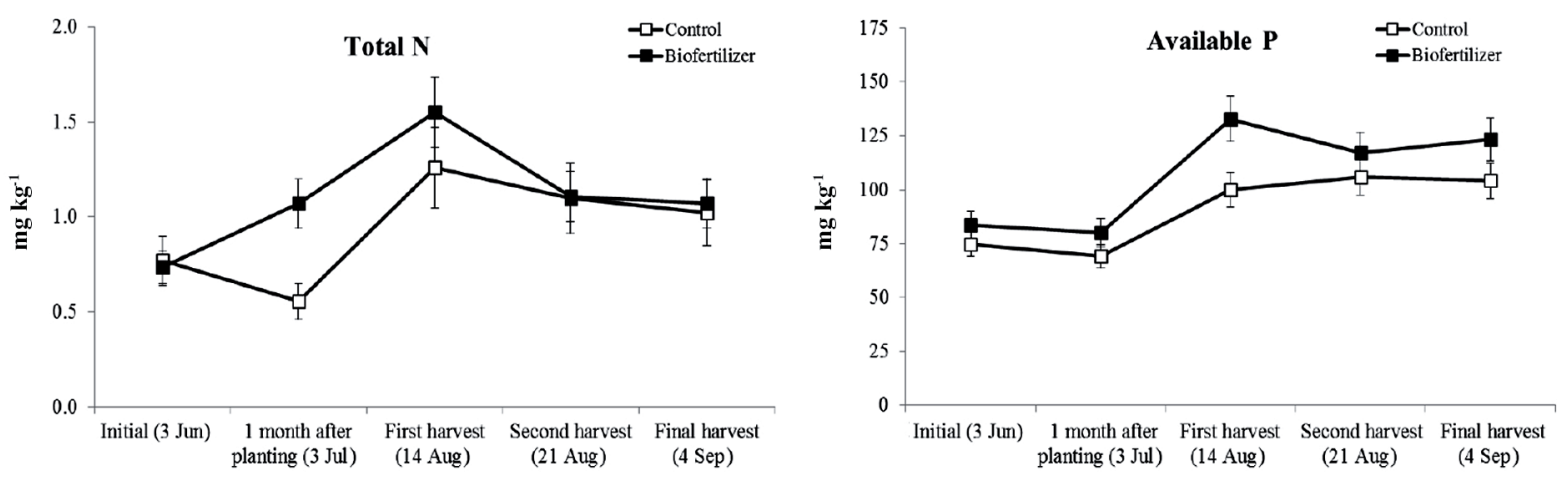

(Table 1). Total $\mathrm{N}$ increased from 1 mo after the biocontroller application until the first harvest (Figure 1), after which it decreased to match the concentration of the control treatment, this indicates high $\mathrm{N}$ consumption at the end of the crop. Many studies have reported that PGPR stimulate the rhizobia-legume symbioses and increase available $\mathrm{N}$ in alfalfa, pea, red clover, and soybean (Andrade et al., 1998; Marek-Kozaczuk and Skorupska, 2001; Gopalakrishnan et al., 2015).

The concentration of exchangeable $\mathrm{Na}, \mathrm{Mg}$, and $\mathrm{K}$ did nonsignificantly decrease at the end of the crop for both treatments (Table 1). However, the exchangeable Na, Mg, and $\mathrm{K}$ concentrations in the biocontroller soil were stable from the first month after application and did not decrease as much as the control soils; this could be attributable to the release of nutrients by the biocontroller, which balances the absorption of these elements by the crop.

Nonsignificant differences were found for available $\mathrm{Zn}$ between treatments (control and biocontroller) and samplings (initial/final) (Table 1). However, available $\mathrm{Mn}, \mathrm{Cu}$, and $\mathrm{Fe}$ concentrations were higher at the end of the crop for both treatments, although only $\mathrm{Cu}$ showed a higher concentration in the treatment plots $\left(4.3 \mathrm{mg} \mathrm{kg}^{-1}\right)$ than the control plots (3.8 $\mathrm{mg} \mathrm{kg}^{-1}$ ). These results indicated that $P$. fluorescens increases soil available $\mathrm{Cu}$, which is available for the next crop cycle. The PGP bacteria are characterized as having the ability to affect micronutrient mobility and availability to the plant by releasing chelating agents, acidification, phosphate solubilization, and redox changes (Gadd, 2010).

Both treatments showed a similar behavior for available micronutrients until the first harvest, decreasing their concentrations 1 mo after the biocontroller application and increasing at the first harvest, especially for Mn and Fe in the control plots (Figure 2). However, the behavior of each element was different at the first harvest; $\mathrm{Zn}$ and $\mathrm{Cu}$ concentrations remained constant until the end of the crop, Fe continued to increase, and Mn decreased and displayed a downward trend. Agarwal et al. (2014) found that P. fluorescens inoculated in soil enhanced micronutrient bioavailability by acidifying the rhizosphere with PGP substances such as indole-3-acetic acid, organic acids, and siderophores. Chen et al. (2014) found a higher $\mathrm{Cu}$ accumulation in Solanum nigrum plant tissues with values from $108 \mathrm{mg} \mathrm{kg}^{-1}$ in the control to $114 \mathrm{mg} \mathrm{kg}^{-1}$ in the plant inoculated with Pseudomonas sp.

Biochemical soil properties did not show any significant differences between treatments and samplings, except for MBC that exhibited significant lower and higher differences between initial ( 85 and $\left.84 \mathrm{mg} \mathrm{C} \mathrm{kg}^{-1}\right)$ and final $(56$ and $93 \mathrm{mg} \mathrm{C} \mathrm{kg}^{-1}$ ) samplings for the control and biocontroller treatments, respectively (Figure 3, Table 1); this indicates that the presence of P. fluorescens increases microbial communities. Kaur and Reddy (2014) showed that a P-solubilizing bacterial population in maize and wheat crops significantly increased due to the inoculation of P.plecoglossicida. In contrast, basal respiration, $\beta$-glucosidase, and phosphatase and urease values in the control and biocontroller treatments showed a similar behavior, these tended to be equal at the end of the experiment. Although not significant, the values of biochemical properties were always higher in the treatment plots than control plots. Fliessbach et al. (2009), in their field experiment on biological properties in soils amended with $P$. fuorescens, concluded that soils poor in MBC and dehydrogenase activity are slightly more susceptible to inoculants than soils that are inhabited by a rich and diverse microflora.

\section{Effect of Pseudomonas fluorescens on the behavior of soil nutrients}

The results of the PCA of the nutrients and biochemical soil properties are shown in Figure 4. Four principal components (PC) with eigenvalues $>1$ were extracted. The PCA led to a reduced initial dimension of the dataset to four factors that explained $81.1 \%$ of the data variation. Therefore, these four factors can be used to explain the effect of $P$. fluorescens on 
Figure 2. Evolution of micronutrients in the control and biocontroller treatment plots.
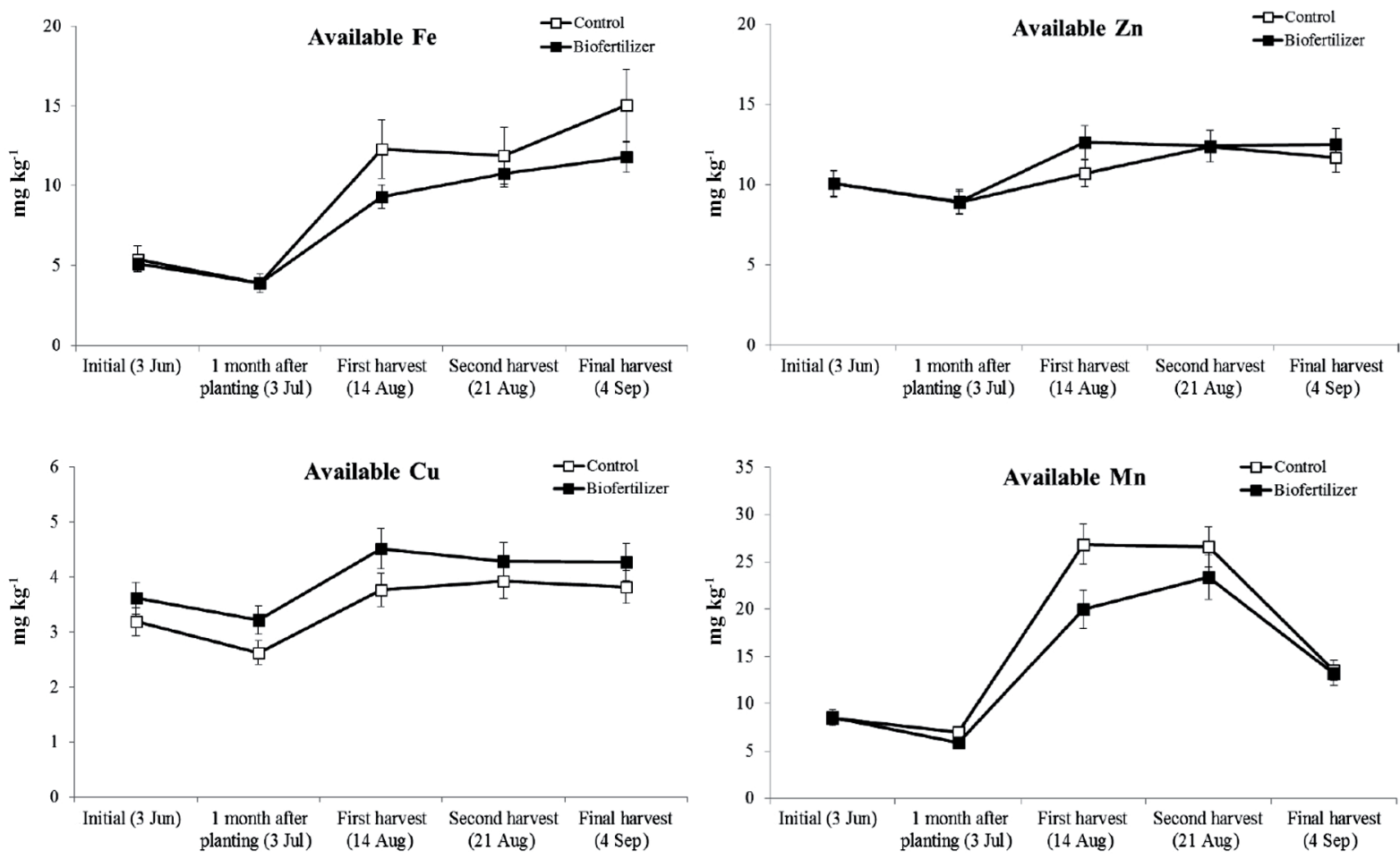

the behavior of soil nutrients. The commonalities shown by the variables ranged from $60 \%$ for basal respiration to $99 \%$ for exchangeable $\mathrm{Ca}$; thus, all the elements were well represented when considering these four factors.

Principal component 1 (PC1), which had high loadings of available $\mathrm{Fe}, \mathrm{Zn}, \mathrm{Cu}, \mathrm{Mn}$, and $\mathrm{P}$, total $\mathrm{N}$, and $\beta$-glucosidase activity, accounted for $30.1 \%$ of the variance. The PC1 indicated that the behavior of soil $\mathrm{Fe}, \mathrm{Zn}, \mathrm{Cu}, \mathrm{Mn}, \mathrm{P}$, and $\mathrm{N}$ is associated with $\beta$-glucosidase activity, which is supported by the Pearson correlation coefficients for $\beta$-glucosidase activity with available $\mathrm{Cu}(\mathrm{r}=0.41, \mathrm{p}>0.05), \mathrm{Mn}(\mathrm{r}=0.43, \mathrm{p}>0.05), \mathrm{P}(\mathrm{r}=0.45, \mathrm{p}>0.05)$, and total $\mathrm{N}(\mathrm{r}=0.52$, $\mathrm{p}>0.05$ ); therefore, an increase of $\beta$-glucosidase activity promotes a release of available soil nutrients. These nutrients could be released into the soil solution from organic matter after $\beta$-glucosidase activity has degraded organic compounds.

Exchangeable $\mathrm{Ca}, \mathrm{K}, \mathrm{Na}$, and $\mathrm{Mg}$ are associated to $\mathrm{PC} 2$, which accounted for $26.3 \%$ of the variance. The negative value for $\mathrm{Ca}$ and positive for the rest of the cations $(\mathrm{K}, \mathrm{Mg}$, and $\mathrm{Na}$ ) indicates that the behavior of these macronutrients is inversely proportional, and it is not directly affected by the application of $P$. fluorescens. However, urease activity showed moderate correlations with $\mathrm{Ca}(\mathrm{r}=-0.51, \mathrm{p}>0.05), \mathrm{K}(\mathrm{r}=0.48, \mathrm{p}>0.05), \mathrm{Na}(\mathrm{r}=0.46, \mathrm{p}>0.05)$, and $\mathrm{Mg}(\mathrm{r}=0.40, \mathrm{p}>$ $0.05)$, phosphatase activity with $\mathrm{Ca}(\mathrm{r}=-0.43, \mathrm{p}>0.05)$ and $\mathrm{K}(\mathrm{r}=0.41, \mathrm{p}>0.05)$, and for $\mathrm{MBC}$ with $\mathrm{Ca}(\mathrm{r}=-0.46, \mathrm{p}>$ $0.05)$ and $\mathrm{Na}(\mathrm{r}=0.44, \mathrm{p}>0.05)$. The negative correlations recorded for phosphatase, urease, and $\mathrm{MBC}$ with Ca reveal that the release of this macronutrient could inhibit these activities.

Phosphatase activity and MBC were positively grouped in PC3, while available Fe was partially and negatively associated with this component and accounted for $13.1 \%$ of the total variance (Figure 4). These results indicated that increased microbial biomass and phosphatase activity reduces the release of available $\mathrm{Fe}$, which could be due to the fact that these bacteria use $\mathrm{Fe}$ in their metabolism to promote its immobilization.

Finally, PC4 only explained $11.6 \%$ of the total variance and was positively loaded on basal respiration and urease activity. Therefore, these biochemical properties do not directly affect the behavior of any soil macro- or micronutrients.

\section{Effect of Pseudomonas fluorescens on nutrient distribution in plant tissues}

Figure 5 displays nutrient distribution ( $\mathrm{Fe}, \mathrm{Zn}, \mathrm{Cu}, \mathrm{Mn}, \mathrm{Ca}, \mathrm{Na}, \mathrm{Mg}, \mathrm{K}, \mathrm{P}$, and $\mathrm{N}$ ) in the tissues of melon plants (leaves and rind). The highest concentrations of $\mathrm{Mn}$ and $\mathrm{N}$ from leaves and $\mathrm{Zn}$ and $\mathrm{P}$ from rind were observed in plots treated with the biocontroller, indicating that $P$. fluorescens promotes the absorption of these nutrients in melon plants. Yao et al. (2018) 
Figure 3. Evolution of biochemical properties in the control and biocontroller treatments plots.
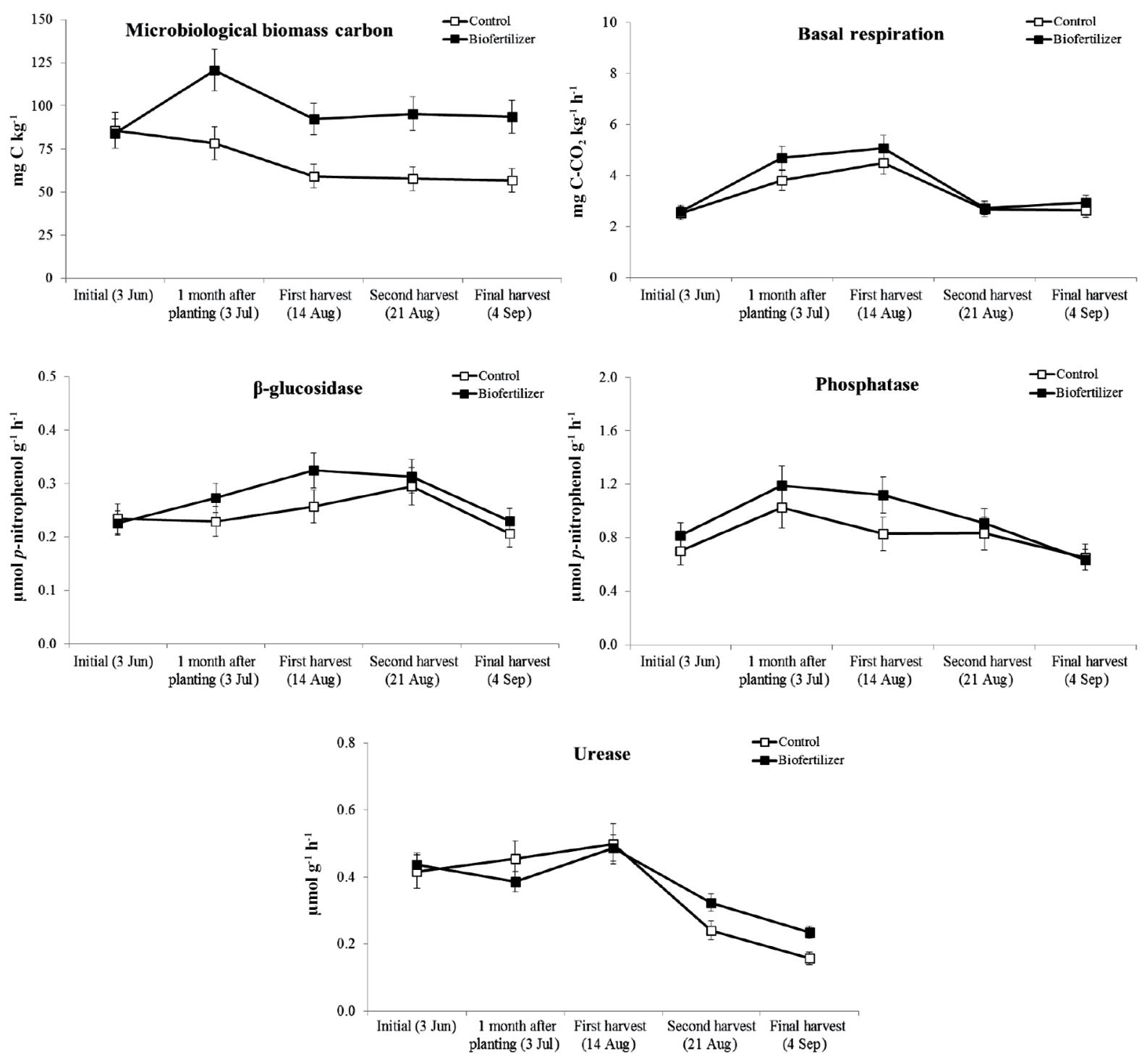

Figure 4. Principal component analysis of nutrients and biochemical properties.
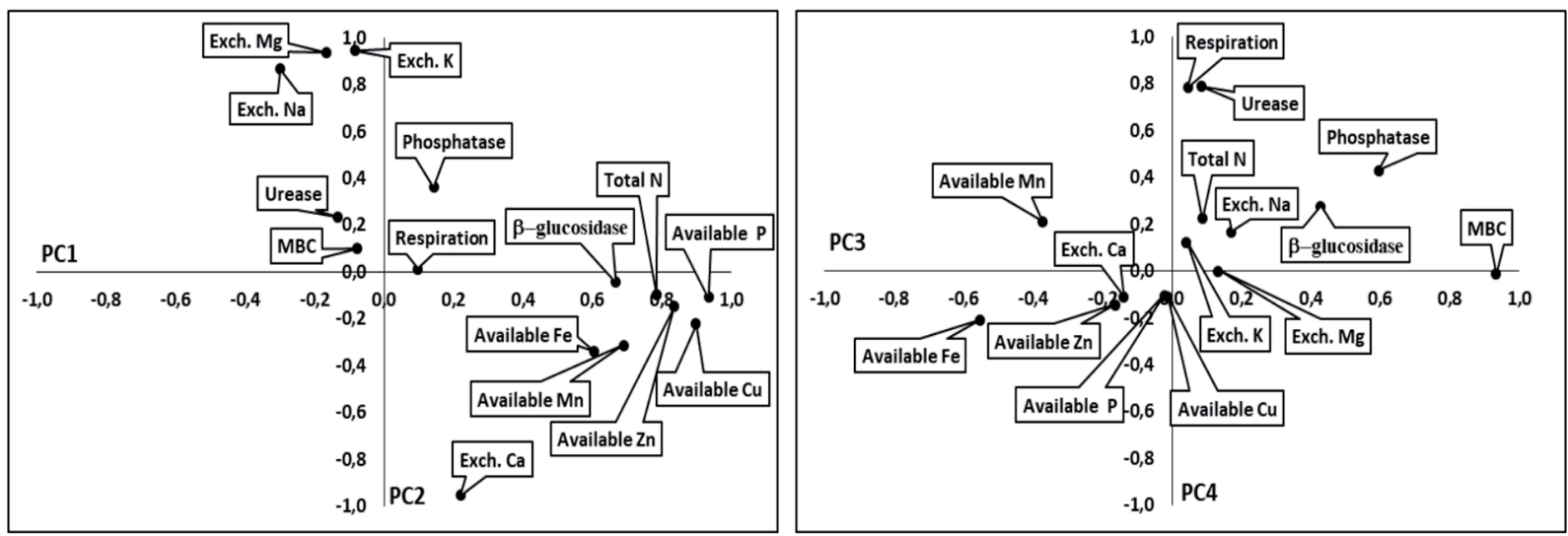

MBC: Microbial biomass C. 
Figure 5. Evolution of nutrients in melon leaves and rind from the control and treated with biocontroller plots.
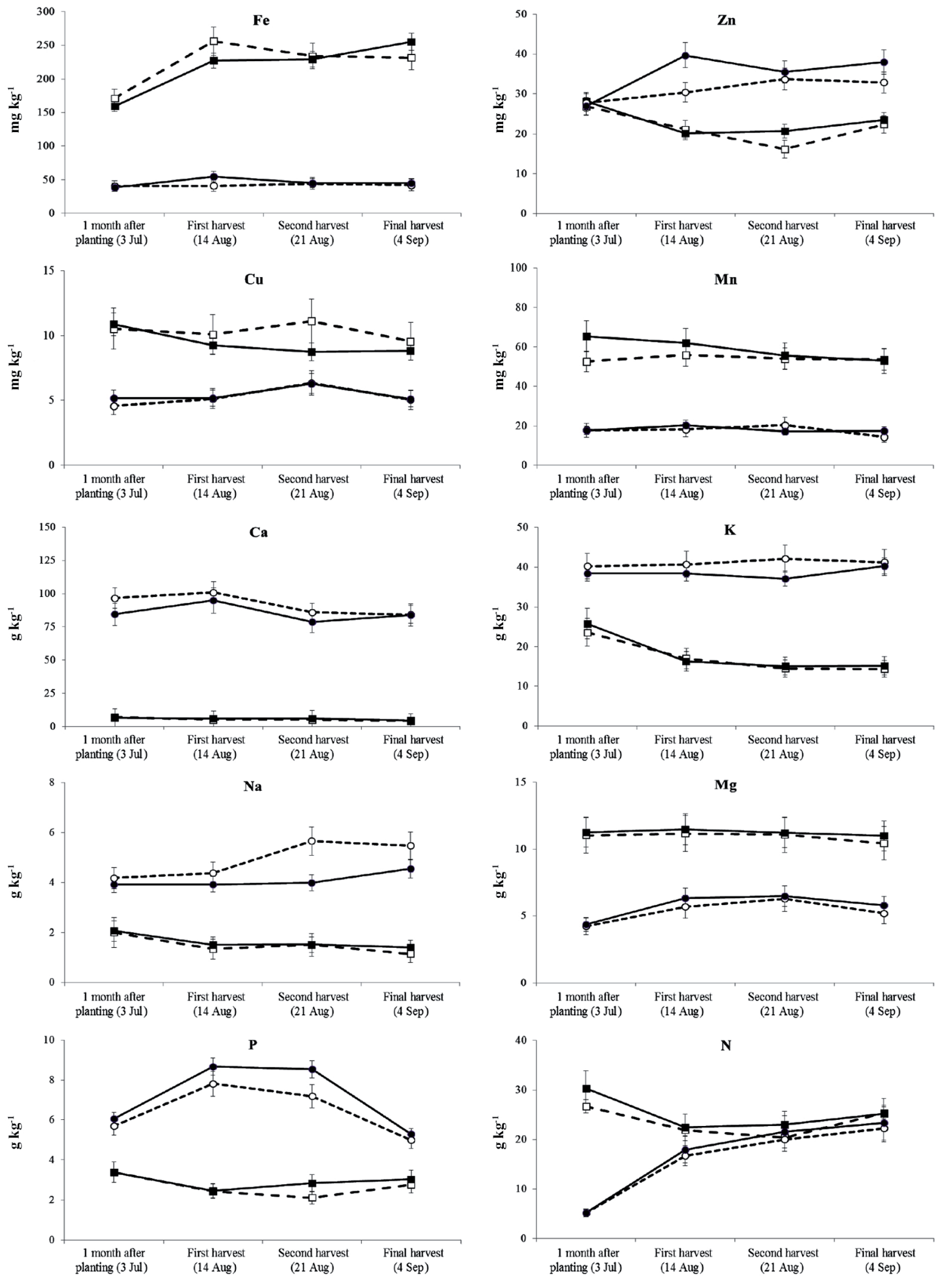
showed that the application of biofertilizers on a rice crop enhanced $\mathrm{N}$ uptake and rice yield. In contrast, concentrations of $\mathrm{Cu}$ from leaves and $\mathrm{Na}, \mathrm{Ca}$, and $\mathrm{K}$ from rind were higher in untreated plots. These results suggest that $P$. fluorescens likely promotes the absorption of $\mathrm{Mn}, \mathrm{N}, \mathrm{Zn}$, and $\mathrm{P}$ and a competition effect among nutrients takes place, which limits $\mathrm{Cu}, \mathrm{Na}$, $\mathrm{Ca}$, and $\mathrm{K}$ absorption by the melon plant. Rodríguez et al. (2013) found significant differences in the concentrations of $\mathrm{Na}$ and $\mathrm{N}$ in watermelon leaves produced in hydroponics and inoculated with growth-promoting bacteria. No differences were found in the concentrations of $\mathrm{Fe}$ and $\mathrm{Mg}$ for the biocontroller application. However, Vansuyt et al. (2007), in their study with $P$. fluorescens applied to Arabidopsis thaliana plants, found an increase of $\mathrm{Fe}$ in plant tissues and improved plant growth.

For both treatments, the concentrations of $\mathrm{Fe}, \mathrm{Cu}, \mathrm{Mn}, \mathrm{Mg}$, and $\mathrm{N}$ were higher in the leaves, while concentrations of $\mathrm{Zn}, \mathrm{Ca}, \mathrm{Na}, \mathrm{K}$, and $\mathrm{P}$ were higher in the rind, with a similar trend between treatments (Figure 5). Except Fe (concentration increased during the crop), $\mathrm{Mg}$ (no effect), and $\mathrm{Ca}$ (no effect), the highest nutrient concentrations were reported in the initial samplings ( 1 mo after planting) for leaves in both treatments, while the concentrations of $\mathrm{Zn}, \mathrm{Na}, \mathrm{Mg}$, and $\mathrm{N}$ in the rind increased during the crop. According to Olaniyi and Fagbayide (2007), the highest $\mathrm{N}$ and $\mathrm{P}$ concentrations were found in the upper leaves of the plants, indicating that these elements decrease with leaf age, unlike $\mathrm{Ca}$ and $\mathrm{Mg}$ that increase with maturity or leaf position.

\section{Effect of Pseudomonas fluorescens on yield quality}

Melon plants were developed with vigor and without any pest or disease problems, which can be due to the biocontroller application (not evaluated in this study). This is supported by results found by Chen et al. (2004) and Hayat et al. (2010), who found that rhizobacteria promote plant development through mechanisms such as phytohormone production and pathogen biocontrol that help crop development and health.

Table 2 shows the results of the quality parameters of melons collected from the control and biocontroller-treated plots during the three samplings (first harvest, second harvest, and final harvest). Overall biocontroller-treated plots had higher mean values compared with the control plot, except for the following samplings where results between treatments were similar: second harvest and final harvest for rind thickness and first harvest and final harvest for pulp hardness.

Collected melon had mean weights of 3.0 to 3.8 and 3.3 to $4.3 \mathrm{~kg}$ for the control and biocontroller treatments, respectively. Rodríguez et al. (2013) also recorded higher weight in their study with P. fluorescens and melon in Mexico (3.9 kg vs. $2.7 \mathrm{~kg}$ for the control treatment). Both the mean weight and mean diameters (axial and equatorial) recorded in the first and second harvests were higher than those recorded at the final harvest; this indicated that the initial stages belonged to fruit formation (from planting to second harvest) and the last stages belonged to fruit maturation (from second harvest to final harvest). Several studies have previously reported that the application of phosphate-solubilizing bacterial strains, such as Bacillus, Pseudomonas, and Enterobacter as bio-inoculants, promote plant growth and enhance grain yield in various crops, including wheat, rice, and sugarcane (Saikia et al., 2012; Tahir et al., 2013; Karpagam and Nagalakshmi, 2014). These results indicated that the application of $P$. fluorescens promoted fruit growth and maturation; typically, bacteria concentration is much higher in rhizosphere soil than in bulk soil, which is due to the presence of sugar, amino acids, organic acids, and other molecules from plant roots exudates (Glick, 2012).

Table 2. Yield quality parameters from the control and biocontroller treatment plots. Mean \pm standard deviation $(n=15)$.

\begin{tabular}{|c|c|c|c|c|c|c|}
\hline & \multicolumn{3}{|c|}{ Control } & \multicolumn{3}{|c|}{ Biocontroller } \\
\hline & $\begin{array}{c}\text { First } \\
\text { harvest } \\
\text { (14 Aug) }\end{array}$ & $\begin{array}{c}\text { Second } \\
\text { harvest } \\
\text { (21 Aug) }\end{array}$ & $\begin{array}{c}\text { Final } \\
\text { harvest } \\
(4 \text { Sep) }\end{array}$ & $\begin{array}{c}\text { First } \\
\text { harvest } \\
\text { (14 Aug) }\end{array}$ & $\begin{array}{l}\text { Second } \\
\text { harvest } \\
\text { (21 Aug) }\end{array}$ & $\begin{array}{c}\text { Final } \\
\text { harvest } \\
\text { (4 Sep) }\end{array}$ \\
\hline Weight, kg & $3.8 \pm 0.2 b^{*}$ & $3.7 \pm 0.3 b$ & $3.0 \pm 0.3 \mathrm{a}$ & $4.3 \pm 0.3 \mathrm{c}$ & $4.3 \pm 0.2 \mathrm{c}$ & $3.3 \pm 0.3 \mathrm{a}$ \\
\hline Axial diameter, $\mathrm{cm}$ & $26.8 \pm 1.0 \mathrm{~b}$ & $25.4 \pm 3.1 \mathrm{ab}$ & $24.7 \pm 1.4 \mathrm{a}$ & $27.2 \pm 1.5 \mathrm{c}$ & $27.3 \pm 1.6 \mathrm{c}$ & $24.8 \pm 1.5 \mathrm{a}$ \\
\hline Equatorial diameter, $\mathrm{cm}$ & $17.7 \pm 0.8 b c$ & $18.0 \pm 2.4 \mathrm{bc}$ & $16.5 \pm 0.9 a$ & $18.3 \pm 0.5 c$ & $18.4 \pm 0.7 \mathrm{c}$ & $17.1 \pm 0.6 \mathrm{a}$ \\
\hline Rind thickness, mm & $3.7 \pm 0.9 b$ & $3.6 \pm 0.9 b$ & $2.4 \pm 0.9 \mathrm{a}$ & $4.0 \pm 1.0 \mathrm{~b}$ & $3.6 \pm 0.8 b$ & $2.4 \pm 0.7 \mathrm{a}$ \\
\hline Pulp thickness, mm & $5.6 \pm 0.6 b$ & $5.5 \pm 0.5 \mathrm{ab}$ & $5.0 \pm 0.4 \mathrm{a}$ & $5.8 \pm 0.6 b$ & $5.7 \pm 0.8 b$ & $5.3 \pm 0.5 \mathrm{ab}$ \\
\hline Pulp hardness, kg & $3.3 \pm 0.3 \mathrm{ab}$ & $3.0 \pm 0.3 \mathrm{a}$ & $3.7 \pm 0.8 b$ & $3.3 \pm 0.3 \mathrm{ab}$ & $3.0 \pm 0.3 \mathrm{a}$ & $3.5 \pm 0.2 b$ \\
\hline Sugar content, ${ }^{\circ}$ Brix & $12.4 \pm 1.4$ & $12.1 \pm 2.7$ & $12.7 \pm 2.0$ & $12.5 \pm 2.3$ & $13.1 \pm 1.6$ & $13.0 \pm 1.6$ \\
\hline
\end{tabular}

*Any two means within a row not followed by the same letter are significantly different at $\mathrm{P} \leq 0.05$. 
The same trend of nonsignificant differences was observed in the mean values of rind thickness: control: $3.7>3.6>$ $2.4 \mathrm{~mm}$ and biocontroller: $4.0>3.6>2.4 \mathrm{~mm}$ and for pulp rind thickness: control: $5.6>5.5>5.0 \mathrm{~mm}$ and biocontroller: $5.8>5.7>5.3 \mathrm{~mm}$ for the first, second, and final harvest, respectively. Regarding the hardness and observed ${ }^{\circ} \mathrm{Brix}$, the highest values were found at the final harvest, pulp hardness: 3.7 and $3.5 \mathrm{~kg}$ and ${ }^{\circ}$ Brix: 12.7 and 13.0 for the control and biocontroller treatments, respectively; although the differences were not significant, the application of $P$. fluorescens could accelerate fruit maturation and therefore the harvest.

\section{CONCLUSIONS}

A single application of Pseudomonas fluorescens in soil promotes salt solubility, especially chlorides; it significantly promotes $\mathrm{Cu}$ and $\mathrm{P}$ availability and microbial $\mathrm{C}$ biomass $(\mathrm{MCB})$ and increases soil total $\mathrm{N}$, and exchangeable $\mathrm{Na}, \mathrm{Mg}$, and $\mathrm{K}$ concentrations.

In addition, $\beta$-glucosidase activity was found to be the responsible for enzymatic activity to release $\mathrm{Fe}, \mathrm{Zn}, \mathrm{Cu}, \mathrm{Mn}, \mathrm{P}$, and $\mathrm{N}$ in the soil. These nutrients could be released to the soil solution from organic matter after $\beta$-glucosidase activity has degraded organic compounds.

The negative correlations recorded for phosphatase, urease, and $\mathrm{MBC}$ with Ca could reveal that an increase of this macronutrient in the soil could inhibit these enzymatic activities. It was also found that increased microbial biomass and phosphatase activity reduced available Fe concentrations, which could be due to the fact that $P$. fluorescens uses Fe in its metabolism to promote its immobilization.

After nutrient analysis from plant tissues, we found that $P$. fluorescens promotes the absorption of $\mathrm{Mn}, \mathrm{N}, \mathrm{Zn}$, and $\mathrm{P}$, which causes a competition effect among nutrients and limits the absorption of $\mathrm{Cu}, \mathrm{Na}, \mathrm{Ca}$, and $\mathrm{K}$ by plants .

Finally, P. fluorescens application increases fruit size and weight; therefore, biofertilization with this bacteria is a sustainable alternative to increase yield and fruit quality without increasing the use of chemical fertilizers and pesticides.

\section{ACKNOWLEDGEMENTS}

This project was funded by SOLBIOSUR S.L. Company; the product used in this work was also supplied by SOLBIOSUR S.L.

\section{REFERENCES}

Agarwal, A., Singh, P.P., and Rai, J.P. 2014. Chromium phytoextraction from tannery effluent-contaminated soil by Crotalaria juncea infested with Pseudomonas fluorescens. Environmental Science Pollution Research 21:79 38-7944.

Andrade, G., DeLeij, F.A., and Lynch, J.M. 1998. Plant mediated interactions between Pseudomonas fluorescens, Rhizobium leguminosarum and arbuscular mycorrhizae on pea. Letters of Applied Microbiology 26:311-316.

Behera, B.C., Singdevsachan, S.K., Mishra, R.R., Dutta, S.K., and Thatoi, H.N. 2014. Diversity, mechanism and biotechnology of phosphate solubilising microorganism in mangrove. A review. Biocatalysis and Agricultural Biotechnology 3:97-110.

Bhattacharyya, P.N., and Jha, D.K. 2012. Plant growth-promoting rhizobacteria (PGPR): Emergence in agriculture. World Journal of Microbiology and Biotechnology 28:1327-1350.

Boddey, R.M., Oliveira, O.C., Urquiaga, S., Reis V.M., Olivares, F.L., Baldani, B.L.D., et al. 1995. Biological nitrogen fixation associated with sugar cane and rice: Contribution and prospects for improvements. Plant and Soil 174:195-209.

Burt, R. 2004. Soil survey laboratory manual. Soil Survey Investigations Report nr 42. Version 4.0 November 2004. USDANatural Resources Conservation Service (NRCS), Lincoln, Nebraska, USA.

Chapman, H.D. 1965. Cation exchange capacity. p. 891-900. In Black, C.A. (ed.) Methods of soil analysis. Part 2. Chemical and microbiological properties. Agronomy Monograph 9.2. American Society of Agronomy, Madison, Wisconsin, USA.

Chen, Y., Clapp, C.E., and Magen, H. 2004. Mechanisms of plant growth stimulation by humic substances: The role of organoiron complex. Soil Science and Plant Nutrition 50:1089-1095.

Chen, L., Luo, S., Li, X., Wan, Y., Chen, J., and Liu, C. 2014. Interaction of Cd hyperaccumulator Solanum nigrum L. and functional endophyte Pseudomonas sp. Lk9 on soil heavy metals uptake. Soil Biology and Biochemistry 68:300-308.

Core, J. 2005. Grafting watermelon onto squash or gourd rootstock makes firmer, healthier fruit. Agriculture Research 53:8-9.

Dobbelaere, S., Vanderleyden, J., and Okon, Y. 2003. Plant growth-promoting effects of diazotrophs in the rhizosphere. Plant Science 22:107-149.

Duchaufour, P.H. 1970. Precis de pedologie. p. 257-280. Masson, Paris, France. 
Esitken, A.S., Ercisli, H., Karlidag, L., and Sahin, F. 2005. Potential use of plant promoting rhizobacteria (PGPR) in organic apricot production. p. 90-97. In Libek, A., Kaufmane, E., and Sasnauskas, A. (eds.) Proceedings of International Scientific Conference of Environmentally Friendly Fruit Growing. 7-9 September. Tartu University Press, Tartu, Estonia.

Fliessbach, A., Winkler, M., Lutz, M.P., Oberholzer, H.R., and Mäder, P. 2009. Soil amendment with Pseudomonas fluorescens CHAo: lasting effects on soil biological properties in soils low in microbial biomass and activity. Microbial Ecology 57(4):611-623.

Fu, L., Penton, C.R., Ruan, Y., Shen, Z., Xue, C., Li, R., et al. 2017. Inducing the rhizosphere microbiome by biofertilizer application to suppress banana Fusarium wilt disease. Soil Biology and Biochemistry 104:39-48.

Gadd, G.M. 2010. Metals, minerals and microbes: geomicrobiology and bioremediation. Microbiology 156:609-643.

Glick, B.R. 2012. Plant growth-promoting bacteria: Mechanisms and applications. Scientifica 2012:ID 963401.

Gopalakrishnan, S., Sathya, A., Vijayabharathi, R., Varshney, R.K., Gowda C.L., and Krishnamurthy, L. 2015. Plant growth promoting rhizobia: challenges and opportunities. Biotechnology 5(4):355-377.

Hayat, R., Ali, S., Amara, U., Khalid, R., and Ahmed, I. 2010. Soil beneficial bacteria and their role in plant growth promotion. A review. Annals of Microbiology 60:579-598.

Jeffery, G.H., Basset, J., Mendham, J., and Denney, R.C. 1989. Vogel's textbook of quantitative chemical analysis. p. $702-703$. Longman Scientific \& Technical, Bath, UK.

Karpagam, T., and Nagalakshmi, P.K. 2014. Isolation and characterization of phosphate solubilizing microbes from agricultural soil. International Journal of Current Microbiology and Applied Sciences 3:601-614.

Kaur, G., and Reddy, M.S. 2014. Influence of P-solubilizing bacteria on crop yield and soil fertility at multilocational sites. European Journal of Soil Biology 61:35-40.

Lindsay, W.L., and Norvell, W.A. 1978. Development of a DTPA soil test for zinc, iron, manganese, and copper. Soil Science Society of America Journal 42:421-428.

Loster, G.E. 2008. Antioxidant, sugar, mineral and phytonutrient concentrations across edible fruit tissues of orange-fleshed honeydew melon (Cucumis melo L.) Journal of Agriculture and Food Chemistry 56:3694-3698.

Madrid, A., Madrid, R., y Vicente, J.M. 1996. Fertilizantes. 436 p. AMV Ediciones y Mundi-Prensa, Madrid, España.

Marek-Kozaczuk, M., and Skorupska, A. 2001 Production of B-group vitamins by plant growth-promoting Pseudomonas fluorescens strain 267 and the importance of vitamins in the colonization and nodulation of red clover. Biology and Fertility of Soils 33:146-151.

Mukhtar, S., Shahid, I., Mehnaz, S., and Malik, K. 2017. Assessment of two carrier materials for phosphate solubilizing biofertilizers and their effect on growth of wheat (Triticum aestivum L.) Microbiological Research 205:107-117.

Nannipieri, P., Ceccanti, B., Cervelli, S., and Matarese, E. 1980. Extraction of phosphatase, urease, protease, organic carbon and nitrogen from soil. Soil Science Society of America Journal 44:1011-1016.

Norusis, M.J. 1993. SPSS for Windows base system user's guide release 6.0. SPSS Inc. IBM, Armonk, New York, USA.

Olaniyi, J.O., and Fagbayide, J.A. 2007. Influence of source and tine of nitrogen application on growth, yield and nutrient composition of Eugosi melon. Research Journal of Agronomy 1:99-104.

Rodríguez, M.N., San Miguel-Chávez, R., García, J.L., y Benavides, A. 2013. Inoculación de bacterias promotoras de crecimiento en el cultivo de melón (Cucumis melo). Interciencia 38:125-131.

Saikia, S.P., Bora, D., Goswami, A., Mudoi, K.D., and Gogoi, A., 2012. A review on the role of Azospirillum in the yield improvement of non-leguminous crops. African Journal of Microbiology Research 6:1085-1102.

Singh, H., and Reddy, M.S. 2012. Improvement of wheat and maize crops by inoculating Aspergillus spp. in alkaline soil fertilized with rock phosphate. Archives of Agronomy and Soil Science 58:535-546.

Tabatabai, M.A. 1982. Soil enzymes. p. 501-538. In Page, A.L., Miller, R.H., Keeney, D.R. (eds.) Methods of soil analysis. Part 2. $2^{\text {nd }}$ ed. Agronomical Monograph N ${ }^{\circ}$ 9. American Society of Agronomy and Soil Science of America, Madison, Wisconsin, USA.

Tabatabai, M.A., and Bremner, J.M. 1969. Use of p-nitrophenyl phosphate in assay of soil phosphatase activity. Soil Biology and Biochemistry 1:301-307.

Tahir, M., Mirza, M.S., Zaheer, A., Dimitrov, M.R., Smidt, H., and Hameed, S. 2013. Isolation and identification of phosphate solubilizer Azospirillum, Bacillus and Enterobacter strains by 16S rRNA sequence analysis and their effect on growth of wheat (Triticum aestivum L.) Australian Journal of Crop Science 7:1284-1292.

Tuhy, L., Chowańska J., and Chojnacka K. 2013. Seaweed extracts as biostimulants of plant growth: review. CHEMIK 67(7):636-641.

Vance, E.D., Brookes, P.C., and Jenkinson, D.S. 1987. An extraction method for measuring soil microbial biomass C. Soil Biology and Biochemistry 19:703-707.

Vansuyt, G., Robin, A., Briat, J.F., Curie, C., and Lemanceau, P. 2007. Iron acquisition from Fe-pyoverdine by Arabidopsis thaliana. Molecular Plant-Microbe Interactions 20:441-447.

Yang, J., Kloepper, J.W., and Ryu, C. 2009. Rhizosphere bacterial help plants tolerate abiotic stress. Trends in Plant Science 14:1-4.

Yao, Y., Zhang, M., Tian, Y., Zhao, M., Zeng, K., Zhang, B., et al. 2018. Azolla biofertilizer for improving low nitrogen use efficiency in an intensive rice cropping system. Field Crops Research 216:158-164.

Zwikel, S., Lavee, H., and Pariente, S. 2007. Temporal evolution of salts in Mediterranean soils transect under different climatic conditions. Catena 70:282-295. 